Original article (Orijinal araştırma)

\title{
Identification, distribution and genetic diversity of Globodera rostochiensis (Wollenweber, 1923) Skarbilovich, 1959 (Tylenchida: Heteroderidae) populations in Turkey
}

\author{
Globodera rostochiensis (Wollenweber, 1923) Skarbilovich, 1959 (Tylenchida: \\ Heteroderidae)'in Türkiye popülasyonlarının tanımlanması, yaygınlık ve genetik çeşitliliği \\ Ahmet ALTAŞ 1 \\ Abdelfattah DABABAT ${ }^{3}$

\section{Emre EVLICE ${ }^{2}$} \\ Göksel ÖZER ${ }^{1}$ \\ Mustafa IMREN ${ }^{1 *}$
}

\begin{abstract}
The golden nematode, Globodera rostochiensis (Wollenweber, 1923) Skarbilovich, 1959 (Tylenchida: Heteroderidae) is one of the most economically important pests of potato in the world. Tests for this nematode are routinely performed for outbreaks and densities in potato growing areas. The morphological and molecular analyses for precise determination of the nematode are employed to establish appropriate management strategies. This study showed that 96\% of soil samples obtained from Bozdağ and Ödemiş Districts of İzmir Province, during 2017 and 2018 potato

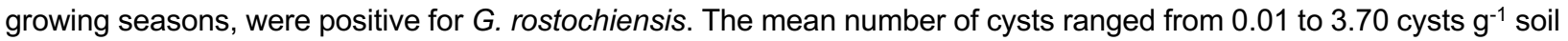
in the fields examined. The examination of the morphological and morphometric features of the second-stage juveniles and cysts of the $G$. rostochiensis revealed slight differences among the populations obtained from Bozdağ and Ödemis. To assess the accuracy of the identification, partial sequences of ribosomal DNA for all populations were amplified, sequenced, and deposited in GenBank. The comparisons of the sequences with those of corresponding $G$. rostochiensis populations available in GenBank showed $99.89-100 \%$ nucleotide similarity. The results of this study will help to better understand the physiology, ecology and biology of the nematode to quarantine this pest more effectively.
\end{abstract}

Keywords: Globodera rostochiensis, ITS, İzmir, morphology, phylogeny

\section{Öz}

Altın nematod, Globodera rostochiensis (Wollenweber, 1923) Skarbilovich, 1959 (Tylenchida: Heteroderidae) dünyada ekonomik açıdan en önemli patates zararlılarından birisidir. Genellikle patates yetiştirilen alanlarındaki dağıımları ve yoğunluklarını belirlemek amacıyla bu nematod için rutin olarak testler gerçekleştirilmektedir. Morfolojik ve moleküler analizler bu nematodun kesin tanısını yapmak ve mücadele stratejilerini oluşturmak amacıyla kullanılmaktadır. Bu çalışma, İzmir İli'nin Bozdağ ve Ödemiş ilçelerinden 2017 ve 2018 yılları patates yetiştiriciliği sezonlarında alınan toprak örneklerinin \%96'sının G. rostochiensis ile enfekte olduğunu göstermiştir. Bulaşık alanlardaki ortalama kist sayısı, 0.01 ila 3.70 kist g$^{-1}$ toprak arasında değişmiştir. Globodera rostochiensis'in ikinci dönem larva ve kistlerinin morfolojik ve morfometrik karakterlerinin incelenmesi, Bozdağ ve Ödemiş'ten elde edilen popülasyonlarda arasındaki hafif farklılıkları ortaya koymuştur. Tanımlamanın doğruluğunu değerlendirmek için, tüm popülasyonlar için kısmi ribozomal DNA sekansları amplifiye edilmiş, sekanslanmış ve GenBank veritabanına kaydedilmiştir. Morfolojik ölçümler ve filogenetik analizler sonucunda Bozdağ ve Ödemiş'ten elde edilen popülasyonlar arasında küçük farklıııların olduğu belirlenmiştir. Sekansların GenBank'ta mevcut karşılık gelen G. rostochiensis popülasyonlarıyla karşılaştıııması sonucunda nükleotid benzerliği \%99.89-100 oranında görülmüştür. Bu çalışmanın sonuçları, bu zararlıyı daha etkili bir şekilde karantinaya almak için nematodun fizyolojisini, ekolojisini ve biyolojisini daha iyi anlamaya yardımcı olacaktır.

Anahtar sözcükler: Globodera rostochiensis, ITS, İzmir, morfoloji, filogenetik

\footnotetext{
${ }^{1}$ Bolu Abant Izzet Baysal University, Faculty of Agriculture and Natural Sciences, Department of Plant Protection, 14030, Bolu, Turkey

2 Plant Protection Central Research Institute, 06172, Yenimahalle, Ankara, Turkey

${ }^{3}$ International Maize and Wheat Improvement Center (CIMMYT), 06511, Emek, Ankara, Turkey

* Corresponding author (Sorumlu yazar) e-mail: mustafaimren@ibu.edu.tr

Received (Alınış): 21.05.2020Ａccepted (Kabul ediliş): 17.06.2020 
Identification, distribution and genetic diversity of Globodera rostochiensis (Wollenweber, 1923) Skarbilovich, 1959 (Tylenchida: Heteroderidae) populations in Turkey

\section{Introduction}

Potato (Solanum tuberosum L. subsp. tuberosum) is the most cultivated tuber crop and an important staple food for over one billion people in the world. It ranks as the fourth for its importance among food crops worldwide; following rice, wheat, and maize (FAOSTAT, 2020). Turkey is in the top ten potato producer countries in Europe with a production area of about 136000 ha. Turkey annually produces about $34 \mathrm{t} \mathrm{ha}^{-1}$, which is still below the average yield potential and the rest (about $40 \mathrm{tha}^{-1}$ ) is being imported from developed countries (FAOSTAT, 2020). Potato yield reduction is attributed to several biotic and abiotic factors, including pests and pathogens (Subbotin et al., 2010). Plant-parasitic nematodes cause an annual loss of $12 \%$ in potato production worldwide (Chitwood, 2003). In tropical and subtropical climates, losses associated with nematodes are estimated at $14.6 \%$ compared to $8.8 \%$ in temperate countries (Sasser \& Freckman, 1987). Among the top 10 plant-parasitic nematodes causing severe economic damage to crops around the world, six genera are resulting yield reduction in potato (Jones et al., 2013). Also, eight species from the seventeen quarantine nematodes declared by the European and Mediterranean Plant Protection Organization (EPPO, 2013) for the Euro-Mediterranean region, are major parasites of potato. Despite their considerable importance, nematodes of potato are not well studied in Turkey (Kepenekci, 2012).

Potato cyst nematodes (PCN), Globodera spp. are obligate parasites resulting in economic damage to potato around the world (Subbotin et al., 2010). These nematodes are quarantined internationally and subjected to strict regulatory measures (Fleming \& Powers, 1998). These nematodes have already been found in 75 countries from Africa, Asia, Europe, North America, South America and Oceania (Ibrahim et al., 2000; Indarti et al., 2004; Andres et al., 2006; Gitty \& Tanha Maafi, 2010). Species of PCN include golden potato cyst nematode, Globodera rostochiensis (Wollenweber, 1923) Skarbilovich, 1959, and pale potato cyst nematode, Globodera pallida Stone, 1973 (Tylenchida: Heteroderidae) are considered harmful quarantine organisms, described in European Union Directives 2000/29/EC and 2009/7/EC and are also part of EPPO A2 List (quarantine species already present in the EPPO region, A2/125 and A2/124, respectively) (EPPO, 2013). These species are regulated by the European Directive 2007/33/EC on the control of PCNs and are subject to stringent regulatory measures when detected singly or in combination (EPPO, 2013). Specific identification of these species is just possible by observation of the female color at the appropriate stage of development, either a change from white to yellow in $G$. rostochiensis or prolonged white (slightly cream but no yellow phase) in G. pallida.

The golden nematode, G. rostochiensis, is a regulated pathogen of potato and a threat to the potato industry in several countries (Scurrah et al., 2005). EPPO has recognized the nematode as plant health quarantine species in the A2 list, which shows the local presence of the pathogen within the EuroMediterranean region. The losses caused by the nematode mainly occurs in temperate regions, in Mediterranean countries, where the host plants are grown from mid-autumn to spring (Mugniéry, 1989). In Turkey, G. rostochiensis was recorded for the first time in 1985 (Enneli \& Öztürk, 1996), following the importing of seed potato from European countries (Baldwin \& Mundo-Ocampo, 1991). The number of infested potato-producing areas in Turkey has significantly increased in the last few years (Kepenekci, 2012). Therefore, the crop protection services observed and reported these nematodes in many potato growing areas in the country (Ulutaş et al., 2012; Imren, 2018; Özarslandan et al., 2019; Toktay et al., 2020).

The pathogenic variability within potato cyst nematode, G. rostochiensis populations is determined by a set of differential host genotypes, and populations are classified into five pathotypes designated as Ro1 to Ro5 (Subbotin et al., 2010). The generation rates of nematode populations on solanaceous plants containing resistance genes can be used to differentiate pathotypes (Kort et al., 1977). The identification of nematode species as well as their pathotype provides crucial information to select appropriate and efficient management strategies (Ganguly \& Rao, 2003). The morphological discrimination of Globodera spp. is conducted via microscopic examination of the structures of cysts and infective juveniles (Golden, 
1990; Siddiqi, 2000; Subbotin et al., 2010). The increasing number of species in the genus Globodera caused difficulties in obtaining sufficient criteria for the differentiation of species and requires highly specialized taxonomists due to the minor morphological and morphometric differences within its species (Subbotin et al., 1999, 2003). Molecular diagnostic techniques based on polymorphism of certain DNA fragments provide fundamental clues to overcome these taxonomic bottlenecks about morphological identification (Szalanski et al., 1997; Al-Banna et al., 2004; Subbotin et al., 2010). The sequences of the ribosomal DNA region including the ITS1, ITS2 and ribosomal genes facilitate reliable and rapid identification of Globodera spp. and differentiate them from other closely related cyst nematode species (Ferris et al., 1995; Subbotin et al., 2000; Madani et al., 2005, 2008; Skantar et al., 2007). The ribosomal DNA region can also be used as excellent genetic markers for diagnostics and the evaluation of phylogenetic relationships due to a large number of copies in individual cells, the lack of recombination, and strict maternal inheritance.

We conducted analyses to understand genetic structures of $G$. rostochiensis populations from two districts (Bozdağ and Ödemiş) of İzmir Province, Turkey. The objectives of the current study were (1) determine the distribution of the $G$. rostochiensis in Izmir Province, (2) to describe and evaluate the morphology and taxonomic features of local G. rostochiensis populations, and (3) to assess phylogenetic relationships of the populations based on the partial of ribosomal DNA sequences.

\section{Materials and Methods}

\section{Nematode populations}

A comprehensive survey was conducted during 2017 and 2018 potato growing seasons to collect soil samples from fields located in Bozdağ and Ödemiş Districts of Izmir Province, Turkey. Samples were taken prior to the potato harvest, between the end of September and the beginning of November (Table 1). Cyst extraction from soil samples was performed using a standard flotation and sieving technique (Southey, 1986). Extracted cysts were firstly categorized to genus level under a V20 model stereo-binocular microscope (Zeiss, Jena, Germany). At least 20 full cysts were selected and handpicked with a needle from each sample and stored at $4^{\circ} \mathrm{C}$ for further use in the morphological and molecular analysis. Additionally, the density of nematodes $\mathrm{g}^{-1}$ of soil was estimated.

Table 1. Location and density of Globodera rostochiensis sampled in this study

\begin{tabular}{|c|c|c|c|c|c|c|}
\hline No & District & Location & Latitude & Longitude & Density (Cyst) & Accession Numbers \\
\hline 1 & Bozdağ & Koca çayır & $38^{\circ} 32^{\prime} 87 \mathrm{~N}$ & $28^{\circ} 05^{\prime} 82 \mathrm{E}$ & 1.60 & MT193688 \\
\hline 2 & Bozdağ & Yukarıçayır & $38^{\circ} 32^{\prime} 90 \mathrm{~N}$ & $28^{\circ} 06^{\prime} 12 \mathrm{E}$ & 0.50 & \\
\hline 3 & Bozdağ & Yukarıçayır & $38^{\circ} 33^{\prime} 03 \mathrm{~N}$ & $28^{\circ} 06^{\prime} 08 \mathrm{E}$ & 0.50 & \\
\hline 4 & Bozdağ & Tekke & $38^{\circ} 33^{\prime} 42 \mathrm{~N}$ & $28^{\circ} 06^{\prime} 22 \mathrm{E}$ & 1.10 & MT193689 \\
\hline 5 & Bozdağ & Nazır & $38^{\circ} 34^{\prime} 68 \mathrm{~N}$ & $28^{\circ} 06^{\prime} 16 \mathrm{E}$ & 0.70 & \\
\hline 6 & Bozdağ & Burunucu & $38^{\circ} 35^{\prime} 35 \mathrm{~N}$ & $28^{\circ} 06^{\prime} 43 \mathrm{E}$ & 1.20 & MT193690 \\
\hline 7 & Bozdağ & Kocaçayırlık & $38^{\circ} 36^{\prime} 22 \mathrm{~N}$ & $28^{\circ} 07^{\prime} 21 \mathrm{E}$ & 1.30 & MT193691 \\
\hline 8 & Bozdağ & Çavdar & $38^{\circ} 33^{\prime} 95 \mathrm{~N}$ & $28^{\circ} 11^{\prime} 48 \mathrm{E}$ & 2.00 & MT193692 \\
\hline 9 & Bozdağ & Çavdar & $38^{\circ} 34^{\prime} 15 \mathrm{~N}$ & $28^{\circ} 11^{\prime} 27 \mathrm{E}$ & 0.70 & \\
\hline 10 & Bozdağ & Büyük çavdar & $38^{\circ} 34^{\prime} 55 \mathrm{~N}$ & $28^{\circ} 11^{\prime} 71 \mathrm{E}$ & 0.50 & \\
\hline 11 & Bozdağ & Gündalan & $38^{\circ} 35^{\prime} 53 \mathrm{~N}$ & $28^{\circ} 10^{\prime} 95 \mathrm{E}$ & 1.20 & MT193693 \\
\hline 12 & Bozdağ & Gündalan & $38^{\circ} 34^{\prime} 84 \mathrm{~N}$ & $28^{\circ} 10^{\prime} 47 \mathrm{E}$ & 3.70 & MT193694 \\
\hline 13 & Bozdağ & Gündalan & $38^{\circ} 35^{\prime} 87 \mathrm{~N}$ & $28^{\circ} 10^{\prime} 01 \mathrm{E}$ & 2.60 & \\
\hline 14 & Bozdağ & Taşııharım & $38^{\circ} 32^{\prime} 52 \mathrm{~N}$ & $28^{\circ} 06^{\prime} 07 \mathrm{E}$ & 1.50 & MT193695 \\
\hline
\end{tabular}


Identification, distribution and genetic diversity of Globodera rostochiensis (Wollenweber, 1923) Skarbilovich, 1959 (Tylenchida: Heteroderidae) populations in Turkey

Table 1. Continued

\begin{tabular}{|c|c|c|c|c|c|c|}
\hline No & District & Location & Latitude & Longitude & Density (Cyst) & Accession Numbers \\
\hline 14 & Bozdağ & Taşlıharım & $38^{\circ} 32^{\prime} 52 \mathrm{~N}$ & $28^{\circ} 06^{\prime} 07 \mathrm{E}$ & 1.50 & MT193695 \\
\hline 15 & Bozdağ & Taşlıharım & $38^{\circ} 32^{\prime} 02 \mathrm{~N}$ & $28^{\circ} 05^{\prime} 82 \mathrm{E}$ & 3.10 & MT193696 \\
\hline 16 & Bozdağ & Ovacık & $38^{\circ} 31^{\prime} 09 \mathrm{~N}$ & $28^{\circ} 05^{\prime} 43 \mathrm{E}$ & 1.10 & MT193697 \\
\hline 17 & Bozdağ & Ovacık & $38^{\circ} 30^{\prime} 64 \mathrm{~N}$ & $28^{\circ} 05^{\prime} 17 \mathrm{E}$ & 1.70 & MT193698 \\
\hline 18 & Bozdağ & Gölcük Adabaşı & $38^{\circ} 30^{\prime} 50 \mathrm{~N}$ & $28^{\circ} 02^{\prime} 42 \mathrm{E}$ & 0.50 & \\
\hline 19 & Bozdağ & Karşıyaka & $38^{\circ} 32^{\prime} 11 \mathrm{~N}$ & $28^{\circ} 03^{\prime} 53 \mathrm{E}$ & 0.20 & \\
\hline 20 & Bozdağ & Gölcük & $38^{\circ} 33^{\prime} 38 \mathrm{~N}$ & $28^{\circ} 03^{\prime} 35 \mathrm{E}$ & 1.40 & MT193699 \\
\hline 21 & Bozdağ & Boğaz & $38^{\circ} 34^{\prime} 09 \mathrm{~N}$ & $28^{\circ} 03^{\prime} 58 \mathrm{E}$ & 0.40 & \\
\hline 22 & Bozdağ & Çayırağzı & $38^{\circ} 34^{\prime} 00 \mathrm{~N}$ & $28^{\circ} 03^{\prime} 75 \mathrm{E}$ & 2.30 & MT193700 \\
\hline 23 & Bozdağ & Aşağı Boğaz & $38^{\circ} 35^{\prime} 13 \mathrm{~N}$ & $28^{\circ} 03^{\prime} 47 \mathrm{E}$ & 1.20 & MT193701 \\
\hline 24 & Bozdağ & Örselli yolu & $38^{\circ} 31^{\prime} 41 \mathrm{~N}$ & $28^{\circ} 02^{\prime} 11 \mathrm{E}$ & 0.40 & \\
\hline 25 & Bozdağ & Subatan & $38^{\circ} 31^{\prime} 80 \mathrm{~N}$ & $27^{\circ} 98^{\prime} 78 \mathrm{E}$ & 2.60 & MT193702 \\
\hline 26 & Bozdağ & Subatan & $38^{\circ} 32^{\prime} 33 \mathrm{~N}$ & $27^{\circ} 99^{\prime} 22 \mathrm{E}$ & 0.80 & \\
\hline 27 & Bozdağ & Subatan & $38^{\circ} 33^{\prime} 74 \mathrm{~N}$ & $27^{\circ} 99^{\prime} 07 \mathrm{E}$ & 0.10 & \\
\hline 28 & Bozdağ & Kireçocağı & $38^{\circ} 46^{\prime} 53 \mathrm{~N}$ & $27^{\circ} 98^{\prime} 52 \mathrm{E}$ & 1.10 & MT193703 \\
\hline 29 & Ödemiş & Küçükavulcuk & $38^{\circ} 24^{\prime} 14 \mathrm{~N}$ & $28^{\circ} 03^{\prime} 47 \mathrm{E}$ & 0.40 & \\
\hline 30 & Ödemiş & Küçükavulcuk & $38^{\circ} 23^{\prime} 76 \mathrm{~N}$ & $28^{\circ} 03^{\prime} 72 \mathrm{E}$ & 1.50 & MT193704 \\
\hline 31 & Ödemiş & Küçükavulcuk & $38^{\circ} 22^{\prime} 86 \mathrm{~N}$ & $28^{\circ} 02^{\prime} 49 \mathrm{E}$ & 0.00 & \\
\hline 32 & Ödemiş & Küçükavulcuk & $38^{\circ} 24^{\prime} 32 \mathrm{~N}$ & $28^{\circ} 02^{\prime} 96 \mathrm{E}$ & 0.70 & \\
\hline 33 & Ödemiş & Büyükavulcuk & $38^{\circ} 23^{\prime} 62 \mathrm{~N}$ & $28^{\circ} 23^{\prime} 16 \mathrm{E}$ & 2.50 & MT193705 \\
\hline 34 & Ödemiş & Gerçekli-Topçukuyu & $38^{\circ} 22^{\prime} 39 \mathrm{~N}$ & $28^{\circ} 06^{\prime} 29 \mathrm{E}$ & 2.10 & MT193706 \\
\hline 35 & Ödemiş & Ocaklı-Türbe & $38^{\circ} 22^{\prime} 88 \mathrm{~N}$ & $28^{\circ} 01^{\prime} 36 \mathrm{E}$ & 1.50 & MT193707 \\
\hline 36 & Ödemiş & Yolüstü-Beylikkırı & $38^{\circ} 20^{\prime} 60 \mathrm{~N}$ & $28^{\circ} 03^{\prime} 37 \mathrm{E}$ & 0.60 & \\
\hline 37 & Ödemiş & Gerekli-Petrol & $38^{\circ} 19^{\prime} 86 \mathrm{~N}$ & $28^{\circ} 04^{\prime} 26 \mathrm{E}$ & 0.20 & \\
\hline 38 & Ödemiş & Gerekli-Canigırı & $38^{\circ} 21^{\prime} 81 \mathrm{~N}$ & $28^{\circ} 05^{\prime} 60 \mathrm{E}$ & 2.10 & MT193708 \\
\hline 39 & Ödemiş & Alidereli & $38^{\circ} 21^{\prime} 46 \mathrm{~N}$ & $27^{\circ} 99^{\prime} 91 \mathrm{E}$ & 0.20 & \\
\hline 40 & Ödemiş & Konaklı-Millik & $38^{\circ} 12^{\prime} 95 \mathrm{~N}$ & $27^{\circ} 99^{\prime} 74 \mathrm{E}$ & 1.30 & MT193709 \\
\hline 41 & Ödemiş & Konaklı-Köy civarı & $38^{\circ} 40^{\prime} 60 \mathrm{~N}$ & $27^{\circ} 36^{\prime} 45 \mathrm{E}$ & 2.10 & MT193710 \\
\hline 42 & Ödemiş & Yeniköy-Karadoğan & $38^{\circ} 23^{\prime} 00 \mathrm{~N}$ & $27^{\circ} 91^{\prime} 40 \mathrm{E}$ & 0.06 & \\
\hline 43 & Ödemiş & Karadoğan-Kırarası & $38^{\circ} 23^{\prime} 85 \mathrm{~N}$ & $27^{\circ} 91^{\prime} 52 \mathrm{E}$ & 0.40 & \\
\hline 44 & Ödemiş & Karadoğan Değirmen & $38^{\circ} 24^{\prime} 48 \mathrm{~N}$ & $27^{\circ} 92^{\prime} 22 \mathrm{E}$ & 1.20 & MT193711 \\
\hline 45 & Ödemiş & Ortaköy-Yumurtacı & $38^{\circ} 24^{\prime} 54 \mathrm{~N}$ & $27^{\circ} 93^{\prime} 35 \mathrm{E}$ & 1.40 & MT193712 \\
\hline 46 & Ödemiş & Ortaköy-Yumurtacı & $38^{\circ} 24^{\prime} 57 \mathrm{~N}$ & $27^{\circ} 93^{\prime} 17 \mathrm{E}$ & 0.08 & \\
\hline 47 & Ödemiş & Yeniköy-Köygirişi & $38^{\circ} 23^{\prime} 91 \mathrm{~N}$ & $27^{\circ} 95^{\prime} 06 \mathrm{E}$ & 0.00 & \\
\hline 48 & Ödemiş & Günlüce Altı & $38^{\circ} 24^{\prime} 92 \mathrm{~N}$ & $27^{\circ} 97^{\prime} 14 \mathrm{E}$ & 0.08 & \\
\hline 49 & Ödemiş & Günlüce at çiftliği & $38^{\circ} 26^{\prime} 21 \mathrm{~N}$ & $27^{\circ} 96^{\prime} 80 \mathrm{E}$ & 1.30 & MT193713 \\
\hline 50 & Ödemiş & Günlüce Riga Çiftlik & $38^{\circ} 25^{\prime} 38 \mathrm{~N}$ & $27^{\circ} 97^{\prime} 05 \mathrm{E}$ & 0.04 & \\
\hline 51 & Ödemiş & Yeniköy-Karapınar & $38^{\circ} 25^{\prime} 13 \mathrm{~N}$ & $27^{\circ} 94^{\prime} 43 \mathrm{E}$ & 0.01 & \\
\hline 52 & Ödemiş & Seviköy Küsküt Mh. & $38^{\circ} 20^{\prime} 21 \mathrm{~N}$ & $27^{\circ} 86^{\prime} 86 \mathrm{E}$ & 1.10 & MT193714 \\
\hline 53 & Ödemiş & Seviköy Akçagün & $38^{\circ} 21^{\prime} 43 \mathrm{~N}$ & $27^{\circ} 85^{\prime} 13 \mathrm{E}$ & 0.04 & \\
\hline 54 & Ödemiş & Yusufdere-Yolkıyı & $38^{\circ} 22^{\prime} 11 \mathrm{~N}$ & $27^{\circ} 84^{\prime} 18 \mathrm{E}$ & 0.02 & \\
\hline 55 & Ödemiş & Kayaköy-Alabaşı & $38^{\circ} 18^{\prime} 51 \mathrm{~N}$ & $27^{\circ} 84^{\prime} 47 \mathrm{E}$ & 2.10 & MT193715 \\
\hline 56 & Ödemiş & Kayaköy-Alabaşı & $38^{\circ} 19^{\prime} 06 \mathrm{~N}$ & $27^{\circ} 83^{\prime} 99 \mathrm{E}$ & 2.10 & MT193716 \\
\hline 57 & Ödemiş & Kayaköy köyaltı & $38^{\circ} 20^{\prime} 04 \mathrm{~N}$ & $27^{\circ} 82^{\prime} 93 \mathrm{E}$ & 3.40 & MT193717 \\
\hline
\end{tabular}




\section{Morphological identification}

The identity of a newly discovered population of potato cyst nematodes, Globodera spp., was first performed based on morphological characteristics of second-stage juvenile (J2) (length of body, stylet and tail, and hyaline portion) and cyst (distance fenestra to anus, fenestra diameter, Granek's ratio, and numbers of cuticular ridges between anus and vulva). Vulva cones were excised from cysts and mounted in Canada balsam (Hooper, 1970). Juveniles were treated by gentle heating $\left(60^{\circ} \mathrm{C}\right)$ and fixed in a TAF solution (triethanolamine, formalin and ultrapure water at a ratio of 2:7:91) and processed to glycerin. TAFfixed specimens were examined under an Axio Lab. A1 model light microscope (Carl Zeiss AG, Oberkochen, Germany). Measurements were estimated using ZEN Lite software with the support of an Axiocam ERc5s digital camera (Carl Zeiss AG, Oberkochen, Germany). The observed features of the cysts and second-stage juveniles were compared with those of reference materials and the description of the neotypes in the literature (Golden \& Ellington, 1972; Manduric et al., 2004).

The data were normalized using the Shapiro-Wilk normality test before they were analyzed using analysis of variance (ANOVA) (Shapiro \& Wilk, 1965). Significant differences among characters were determined using protected least significant differences using SPSS statistical software V 17.0 (IBM Corp., Armonk, NY, USA) at $P<0.001$. The standard test of means was conducted to detect the significant variance between populations $(P \leq 0.05)$.

\section{Molecular identification}

DNA was extracted from each population using the Worm Lysis Buffer Method (WLB) (Waeyenberge et al., 2000). A single $\mathrm{J} 2$ from a single cyst was handpicked and transferred into a $0.2 \mathrm{ml}$ tube containing $10 \mu \mathrm{l}$ sterile ultrapure water. Then $8 \mu \mathrm{l}$ of lysis buffer $(100 \mathrm{mM}$ Tris-Cl, $500 \mathrm{mM} \mathrm{KCl} ; 15 \mathrm{mM} \mathrm{MgCl}, 10 \mathrm{mM}$ dithiothreitol, $0.1 \%$ gelatin, and 4.5\% Tween 20) and $2 \mu$ l of proteinase K (Cat No./ID: 19131 Qiagen $\mathrm{GmbH}$, Hilden, Germany) at $600 \mu \mathrm{g} / \mathrm{ml}$ were added to the mix in the tube. The microtube was heated to $65^{\circ} \mathrm{C}$ in a DB-100 dry-block heater (Techne, Cambridge, UK) for $1 \mathrm{~h}$, and consecutively to $95^{\circ} \mathrm{C}$ for 5 min to inactivate the proteinase $\mathrm{K}$ (Holterman et al., 2006). The lysate was centrifuged at $16,000 \mathrm{~g}$ for $5 \mathrm{~min}$ and the supernatant was transferred into a new $0.2 \mathrm{ml}$ tube and stored at $-20^{\circ} \mathrm{C}$ for further use. F194 (5'CGTAACAAGGTAGCTGTAG-3') and F195 (5'-TCCTCCGCTAAATGATATG-3') primers developed by Ferris et al. (1993) were used for amplification of the ITS for all samples. PCR reactions were carried out in a total volume of $50 \mu \mathrm{l}$ containing $1 \mu \mathrm{l}$ of nematode lysate, $1 \times$ Ammonium Buffer, $1 \mu \mathrm{M}$ each of primers, $0.2 \mathrm{mM}$ dNTPs and 1-unit Ampliqon TEMPase Hot Start DNA polymerase (Berntsen, Rødovre, Denmark). Three PCR reactions lacking DNA (no template control) were also performed. PCR amplification was conducted in a T100 thermal cycler (Bio-Rad Laboratories, CA, USA) programmed as follows: initial denaturation at $94^{\circ} \mathrm{C}$ for $15 \mathrm{~min}$ followed by 30 cycles of $30 \mathrm{~s}$ at $94^{\circ} \mathrm{C}, 30 \mathrm{~s}$ at $58^{\circ} \mathrm{C}, 45 \mathrm{~s}$ at $72^{\circ} \mathrm{C}$ and a final extension at $72^{\circ} \mathrm{C}$ for $5 \mathrm{~min}$. PCR products were detected by electrophoresis on $1.2 \%$ agarose gels and visualized by staining with ethidium bromide. The DNA banding patterns were visualized and documented by a G:Box F3 gel documentation system (Syngene, UK). PCR products were subjected to bidirectional sequencing by a commercial company (Macrogen Inc., Seoul, Korea) after purification with Wizard SV Gel and PCR Clean-Up System (Promega, Madison, WI, USA) according to the manufacturer instructions.

\section{Phylogenetic analysis}

A BLAST search for ITS sequences was performed in the GenBank database to determine the closest available reference sequences in the complete nucleotide collection of the National Center for Biotechnological Information (NCBI; http://blast.ncbi.nlm.nih.gov). All sequences of the populations obtained in the present study were deposited in the GenBank database under accession numbers from MT193688 to MT193717 (Table 1). The sequence with those of corresponding G. rostochiensis population from different countries available in the GenBank nucleotide database (EF622522 from Australia, 
FJ212167 from Canada; KR057953 from Serbia, DQ847117 from the USA, JF907550 from Poland and MT193701 from Japan) were aligned with Clustal W (Thompson et al., 1994) and edited manually using MEGAX (Kumar et al., 2018). The maximum likelihood method was performed to construct a phylogenetic tree from the sequence data using MEGAX software based on the General Time Reversible model (Tamura $\&$ Nei, 1993). The confidence of phylogenetic tree topologies was confirmed by bootstrap analysis from 1,000 replicates (Felsenstein, 1985). The sequence of $G$. pallida population from the USA (EF153837) was included as an outgroup to root the phylogenetic tree.

\section{Results and Discussion}

The morphological and molecular identification confirmed the presence of the golden nematode, $G$. rostochiensis, in the surveyed areas. Globodera rostochiensis was detected in potato fields located both in Bozdag, with the mountain slopes at an altitude of about 1,000 m, and in flat areas in Ödemiş. Overall, 55 of 57 soil samples $(96 \%)$ obtained from Bozdağ and Ödemiş Districts were found being infected with $G$. rostochiensis. Two locations in Ödemiş were found free of potato cyst nematode (Table 1). In Turkey, first report of the presence of $G$. rostochiensis was declared in 1996 from a field of seed potatoes in Dörtdivan District of Bolu Province (Enneli \& Öztürk, 1996). Although, strict regulatory measures have been enforced to prevent further spread of nematode; it was not possible to completely prevent it from contaminating important potato producing areas in Turkey (Kepenekci, 2012). Ulutaş et al. (2012) reported that G. rostochiensis was found in 17 and $62 \%$ of the fields investigated in the Aegean Region and Ödemis District, respectively. Since then, a remarkable increase has occurred in the incidence of infestation of potato cultivation areas in Izmir Province. The presence of the nematode has recently been confirmed by Demirbaş Pehlivan et al. (2020). This phenomenon requires the extension services and quarantine departments to establish a control method to minimize the population of $G$. rostochiensis in the infested areas.

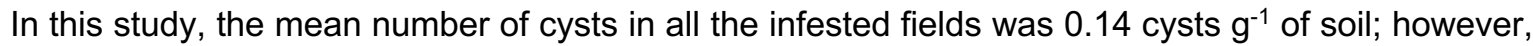
the infestation levels of $G$. rostochiensis varied between the surveyed locations. The fields with less than

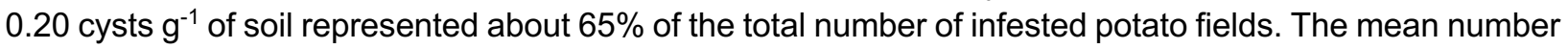
of cysts of $0.21-0.50$ represented $19 \%$ of infested fields, and the average of more than 0.5 cysts represented only $4.2 \%$ of the surveyed fields (Table 1$)$. The highest density of cysts ( $3.70 \mathrm{~g} \mathrm{~g}^{-1}$ of soil) was found in Gündalan in Bozdağ (sample 57) and the other higher densities were 3.40 and 3.10 cysts g $^{-1}$ of soil in Kayaköy-Köyaltı location of Ödemiş (sample 15) and in Taşlıharım location Bozdağ (sample 12), respectively. The lowest cyst density $\left(0.01 \mathrm{~g} \mathrm{~g}^{-1}\right.$ of soil) was found in Yeniköy-Karapınar (sample 51) and the other lower densities were 0.02 and 0.04 cysts $\mathrm{g}^{-1}$ of soil found in Yusufdere Yolkıyı (sample 54) and Günlüce-Riga Çiftlik (sample 50) location of Ödemiş, respectively. Similarly, Özarslandan et al. (2019) reported that the mean cysts number of $G$. rostochiensis in the soil was found 0.24 cysts $\mathrm{g}^{-1}$ of soil in Nevşehir Province in the Central Anatolia Region, Turkey. The occurrence and density of G. rostochiensis in potato growing areas in Izmir Province would ultimately reach the economic threshold levels. Greco et al. (1982) reported that the loss threshold for G. rostochiensis and G. pallida in Italian potato growing areas was between 1.4 and 2.1 eggs g $^{-1}$ of soil, respectively. Also, the economic threshold for $\mathrm{G}$. rostochiensis in the UK is calculated as 15 eggs $\mathrm{g}^{-1}$ of soil (Dale, 1988). Therefore, it is recommended to establish a strategy of combining cultural control methods including crop rotation with non-host crops and the use of resistant potato cultivars. The application of chemicals should be limited to avoid environmental pollution or deterioration of the physical properties of the soil.

Second-stage juveniles of $G$. rostochiensis had cylindrical bodies, tapering at both extremities, mostly posterior (Figure 1a). The tail was shortened, and the head was slightly offset with prominent cephalic sclerotization and rounded. The stylet was visible and anteriorly flattened to rounded knobs. The median bulb was ellipsoidal with a prominent valve. Esophageal glands extended ventrally for about 35 
percent of body length (Figure 1b). Genital primordium located about 60 percent of body length. Tail tapered to a finely rounded terminus (Figure 1c).

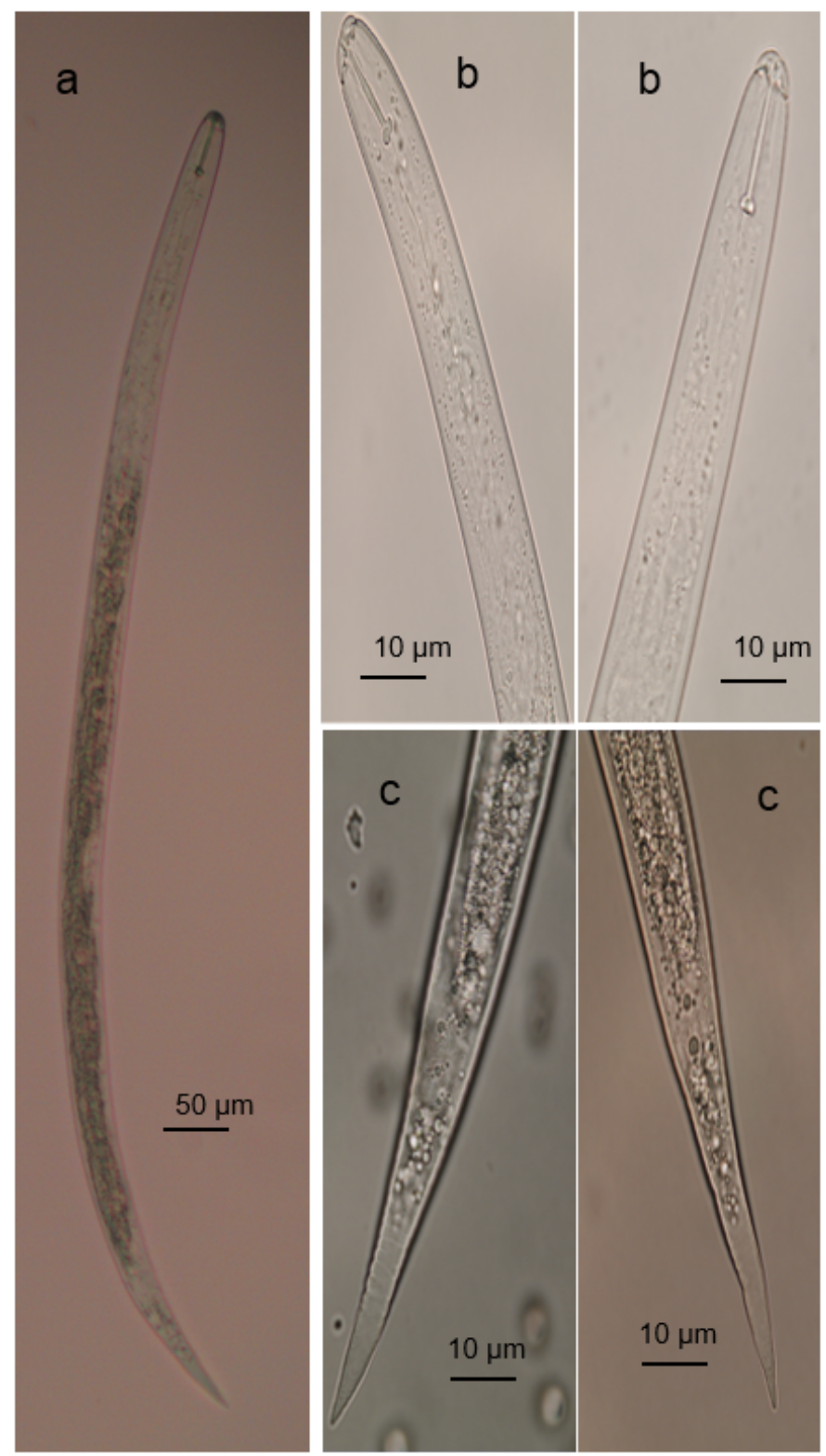

Figure 1. Second-stage juveniles of Globodera rostochiensis from İzmir. Specimens from İzmir: (a) body, (b) heads, and (c) tails.

In the Bozdağ populations, the body length of juveniles varied from 399 to $496 \mu \mathrm{m}$, and stylet length was 19 to $22 \mu \mathrm{m}$ with rounded, slightly backward sloping stylet knobs (Table 2). Tail length and hyaline length were 38 to $46 \mu \mathrm{m}$ and 17 to $28 \mu \mathrm{m}$, respectively. Among Ödemiş populations, the body length varied from 418 to $550 \mu \mathrm{m}$, and stylet length was $19-23 \mu \mathrm{m}$ with anteriorly indented stylet knobs. Tail length and hyaline length were 32 to $56 \mu \mathrm{m}$ and 21 to $30 \mu \mathrm{m}$, respectively (Table 2). Similarly, Wouts \& Baldwin (1998) and Siddiqi (2000) stated that body length ranged from 445 to $510 \mu \mathrm{m}$, stylet length was 18 to $29 \mu \mathrm{m}$, tail length was 37 to $55 \mu \mathrm{m}$ and the hyaline tail part was 21 to $31 \mu \mathrm{m}$ for the second stages juveniles of $G$. rostochiensis, which was in accordance with our results. 
Identification, distribution and genetic diversity of Globodera rostochiensis (Wollenweber, 1923) Skarbilovich, 1959 (Tylenchida: Heteroderidae) populations in Turkey

Table 2. Morphometrics (in $\mu \mathrm{m}$ ) of second-stage juveniles of Globodera rostochiensis from Izmir Province, Turkey

\begin{tabular}{lcccccc}
\hline \multirow{2}{*}{ Characters } & \multicolumn{3}{c}{ Bozdağ population } & \multicolumn{3}{c}{ Ödemiş population } \\
\cline { 2 - 7 } & Range & Mean & SD & Range & Mean & SD \\
\hline Body length & $399-496$ & 452.00 & 5.00 & $418-550$ & 470.00 & 7.00 \\
Stylet length & $19-22$ & 19.80 & 0.20 & $19-23$ & 20.90 & 0.70 \\
Tail length & $38-46$ & 41.40 & 1.12 & $32-56$ & 47.26 & 2.30 \\
Hyaline tail terminal length & $17-28$ & 20.64 & 1.14 & $21-30$ & 27.80 & 1.55 \\
\hline
\end{tabular}

The average values of morphological characters of second-stage juveniles were larger in populations of G. rostochiensis from Ödemiş than those from Bozdag (Table 2). However, the differences in body length and tail length between Ödemiş and Bozdağ populations were not significant $(P \leq 0.5)$. The morphological average values of the $\mathrm{J} 2$ of $\mathrm{G}$. rostochiensis were consistent with the range described in previous studies (Fleming \& Powers, 1998; EPPO, 2013). For all 30 populations, the morphological characters of J2s, especially body length and tail length, were consistent with Wouts and Baldwin (1998). However, the measurements of the J2s slightly differed from those estimated by Golden (1986), who measured a longer tail length $(42$ to $67 \mu \mathrm{m})$ and a longer hyaline length $(20$ to $36 \mu \mathrm{m})$. According to their round shape and light-brown color cysts, populations were considered as $G$. rostochiensis.

The cysts were brown or yellow, spherical or subspherical in shape, with protruding necks and lacking a terminal cone. Cysts had a small projecting neck and with tanned brown skin. The cuticle surface had a zigzag pattern of ridges and a distinct D-layer was present. The perineal area consisted of a single circumfenestration around the vulval slit in vulval basin; underbridge and bullae were rarely present (Figure 2). Morphometric data for larvae also indicates similarity to G. rostochiensis (Table 3). Morphometrics of cyst perineal region G. rostochiensis (Table 3) provided clear differences between populations of Ödemiş and Bozdağ. The populations from Ödemiş had the largest values of vulva-anus distance, the number of cuticular ridges between vulva and anus, and Granek's ratio, fitting well within ranges of $G$. rostochiensis whereas populations from Bozdağı had small mean values of Granek's ratio and the number of cuticular ridges overlapping of $G$. rostochiensis (Subbotin et al. 2010).

Table 3. Morphometrics (in $\mu \mathrm{m}$ ) of second-stage juveniles of Globodera rostochiensis from Izmir Province, Turkey

\begin{tabular}{|c|c|c|c|c|c|c|}
\hline \multirow{2}{*}{ Characters } & \multicolumn{3}{|c|}{ Bozdağ population } & \multicolumn{3}{|c|}{ Ödemiş population } \\
\hline & Range & Mean & SD & Range & Mean & SD \\
\hline Body length excluding neck & $423-592$ & 521 & 7 & $469-712$ & 587 & 8 \\
\hline Body with & $389-545$ & 472 & 12 & $446-610$ & 534 & 10 \\
\hline Distance from anus to nearest edge of fenestra (anus-vulva) & $52-68$ & 58.4 & 1.4 & $56-71$ & 66.6 & 2 \\
\hline Fenestra length & $17-23$ & 18.6 & 0.2 & $18-26$ & 21.6 & 1.2 \\
\hline Number of cuticular ridges between vulva-anus & $18-21$ & 19 & 0.2 & $19-24$ & 22 & 0.4 \\
\hline Granek's ratio & $2.63-4.0$ & 3 & 0.3 & $2.9-4.2$ & 3.7 & 0.6 \\
\hline
\end{tabular}

The cyst length of $G$. rostochiensis for Bozdağ populations varied from 423 to $592 \mu \mathrm{m}$, and body width was 389 to $545 \mu \mathrm{m}$ with a spherical shape, with a short neck and no terminal cone. The anus to vulva and fenestra length were 52 to $68 \mu \mathrm{m}$ and 17 to $23 \mu \mathrm{m}$, respectively. The number of cuticular ridges between vulva-anus and Granek's ratio were 18 to 21 and 2.63 to 4.00 (Table 3). The cyst length of $G$. rostochiensis for Ödemiş populations ranged from 469 to $712 \mu \mathrm{m}$ and body width varied from 446 to 610 $\mu \mathrm{m}$ with a spherical shape, small projecting neck, lacking terminal cone. The anus to vulva and fenestra length were 56 to $71 \mu \mathrm{m}$ and 18 to $26 \mu \mathrm{m}$, respectively. The number of cuticular ridges between vulva-anus and Granek's ratio were 19 to $24 \mu \mathrm{m}$ and 2.9 to 4.2, respectively. Likewise, Wouts \& Baldwin (1998), Siddiqi (2000) reported that cyst length without neck and width were 423 to $592 \mu \mathrm{m}$ and 469 to $712 \mu \mathrm{m}$. The neck 
length and mean fenestral diameter were $104 \pm 19 \mu \mathrm{m}$ and $19.0 \pm 2.0 \mu \mathrm{m}$. The fenestral length and Granek's ratio were $20 \mu \mathrm{m}$ and 3.0, respectively.
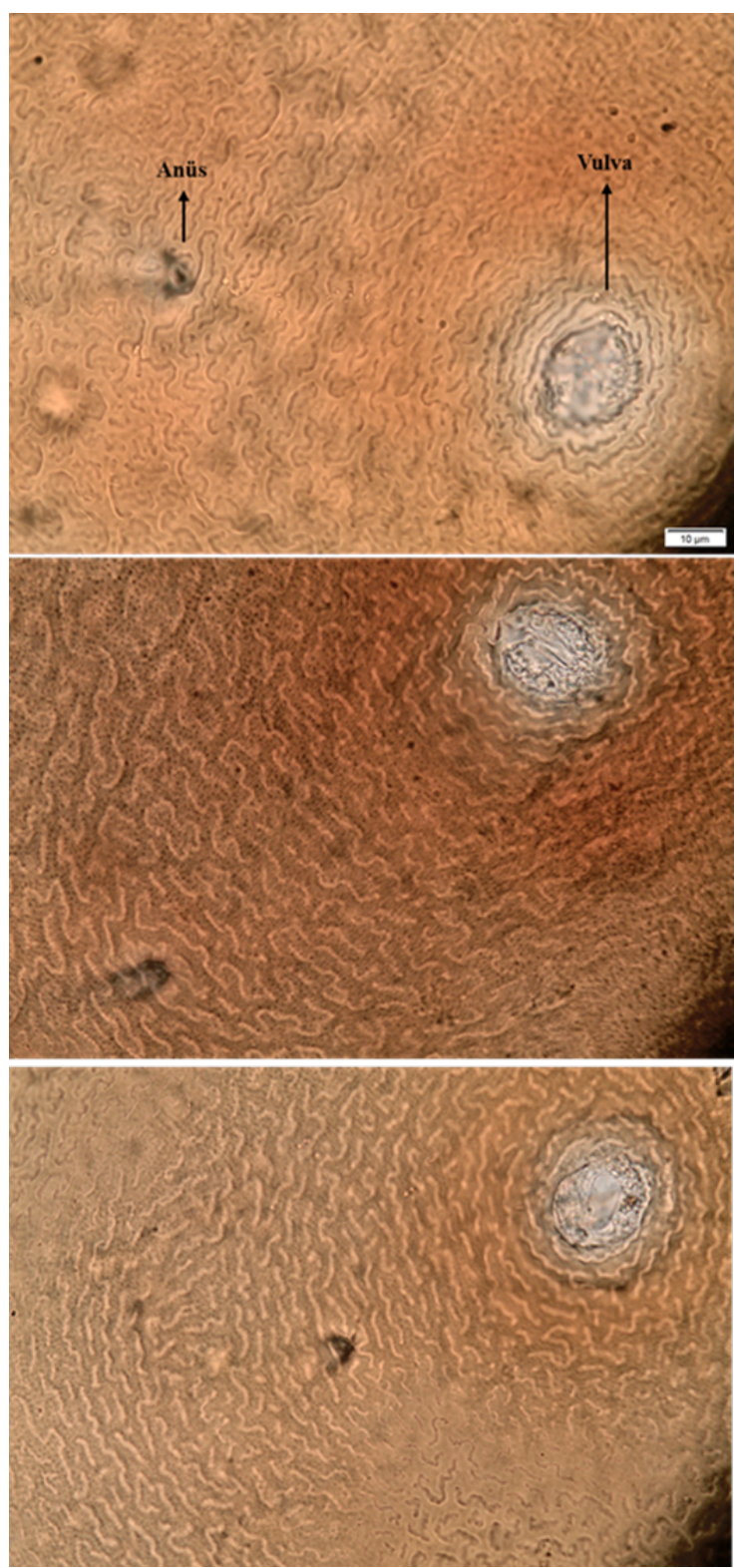

Figure 2. Photomicrographs of the anal-vulval regions of Globodera rostochiensis cysts from Izmir Province, Turkey.

The mean morphological and morphometric values of cysts were higher for Ödemiş populations than those of Bozdağ populations (Table 3). However, the differences between Ödemiş and Bozdağ populations were not significant $(P \leq 0.5)$ for number of ridges and anus-vulva distance. Also, the average values associated with the morphological and morphometric features of the cysts were within the range described in previous studies (Fleming \& Powers, 1998; EPPO, 2013). For all populations, the overlap was high in cysts morphological and morphometric characters especially fenestral length and Granek's ratio with Wouts \& Baldwin (1998), but these values were slightly differed clearly from other Golden (1986) by slightly higher mean in the distance from anus to the nearest edge of fenestra $58.4(52-68 \mu \mathrm{m})$. 
All samples produced a single fragment of about 950 bp using F194 and F195 primers. The amplified sequences were used as BLAST queries against the NCBI database and had $99.89-100 \%$ nucleotide similarity with those of corresponding species recorded in GenBank. The result of the study, 30 cyst populations from Bozdağ and Ödemis locations compared with closely related cyst samples in GenBank and were all identified as $G$. rostochiensis based on their ITS sequences. The G. rostochiensis populations in this study were compared molecularly with international genotypes from different countries (Figure 3). The analysis involved 37 nucleotide sequences. The clustering of the populations on the phylogenetic tree that occurred according to their species levels based on genetic distance was constructed from the ITS sequence alignment (Figure 3).

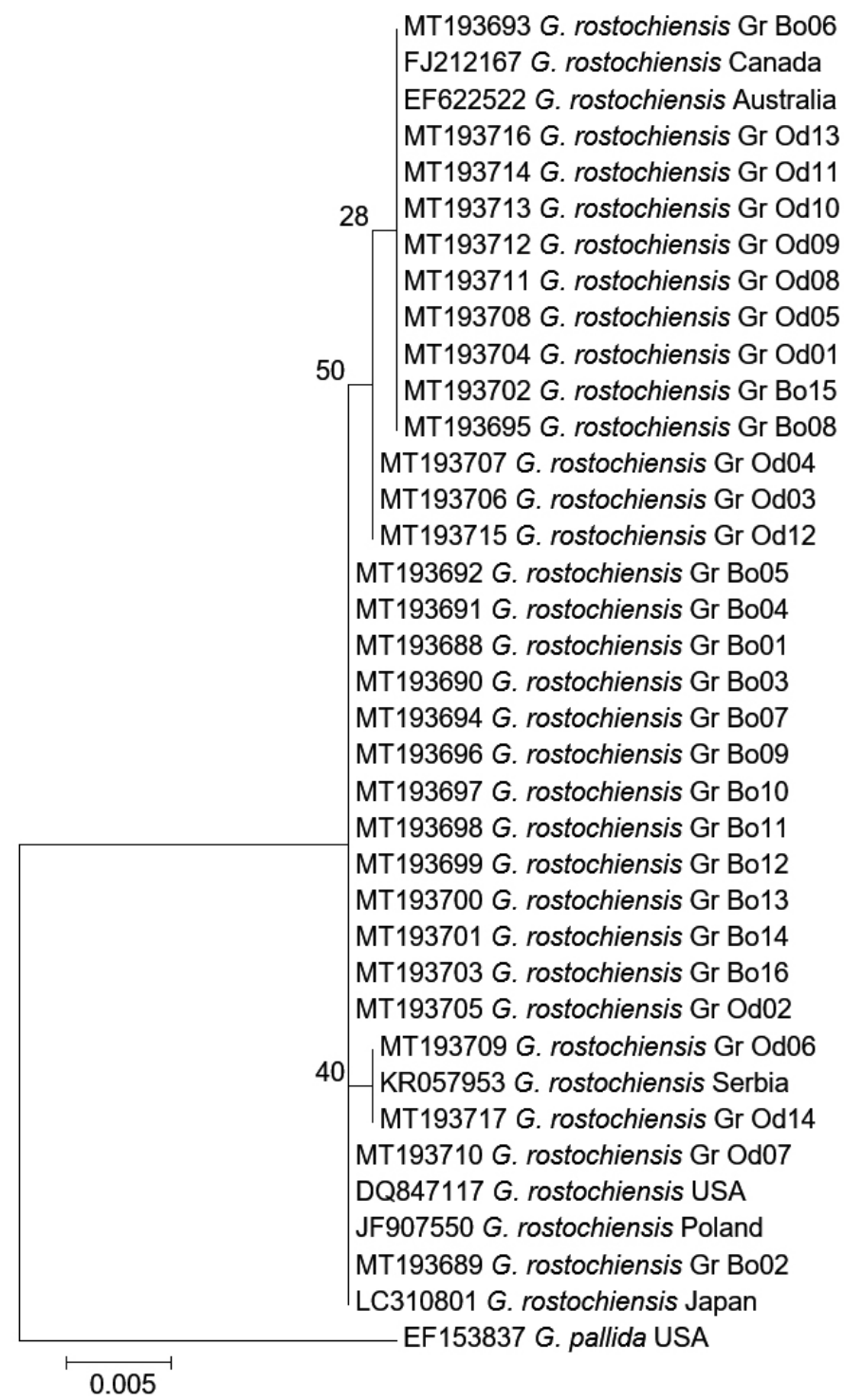

Figure 3. Maximum likelihood tree was generated using the ITS sequences of populations of Globodera rostochiensis and reference populations from GenBank including their accession numbers and strain numbers. Numbers on the branches represent bootstrap values obtained from 1,000 bootstrap replications. 
However, Madani et al. (2010) reported that G. rostochiensis populations from different locations in Canada were clustered in one group within the phylogenetic tree. Knoetze et al. (2013) reported that the ITS sequence alignment of $G$. rostochiensis populations from South Africa clustered together with a high bootstrap value similarity using the minimum evolution method. Different cyst nematode species were thought to be phylogenetically examined based on ITS sequences and this region was thought to be useful in identifying species (Subbotin et al., 2000). Therefore, the slight distances among G. rostochiensis population can be explained by high gene flow among potato cyst nematode populations.

Population diversity within the genus Globodera has often been used successfully for diagnostic purposes to discriminate G. rostochiensis populations from non-quarantine species (Baldwin \& MundoOcampo, 1991; Fleming \& Powers, 1998; Manduric et al., 2004). This study is the first to provide a comprehensive molecular analysis of $G$. rostochiensis populations from Izmir and is complementary to other studies of Turkish potato cyst nematodes populations. This study emphasized the agroecological distribution of the potato cyst nematode species G. rostochiensis in Bozdağ and Ödemiş Districts in İzmir. The differences determined by morphological and morphometric techniques also demonstrated a variation among G. rostochiensis populations, indicating that climatic conditions of the mountainous area could influence variability. It is be concluded that the results of this study will help to investigate more of pathotypes of golden nematode and to gain a more complete understanding of the physiology, ecology and biology of the genus Globodera as agricultural pests for an effective management.

\section{Acknowledgements}

The authors would like to thank the Doğal Pesticides and Chemicals Industry Trade S.A. for providing the funding for this study. For technical assistance, we also thank Nancy De Sutter from the Flanders Research Institute for Agriculture, Fisheries and Food, Belgium.

\section{References}

Al-Banna, L., A. T. Ploeg, V. M. Williamson \& I. Kaloshian, 2004. Discrimination of six Pratylenchus species using PCR and species-specific primers. Journal of Nematology, 36 (2): 142-146.

Andres, M. F., R. Alonso \& A. Alemany, 2006. First report of Globodera rostochiensis in Mallorca Island, Spain. Plant Disease, 90 (9): 1262-1262.

Baldwin, J. G. \& M. Mundo-Ocampo, 1991. "Heteroderinae, Cyst and Non-Cyst Forming Nematodes, 275-362". In: Manual of Agricultural Nematology (Eds. W. R. Nickle \& M. Dekker). CRC Press, 1035 pp.

Chitwood, D. J., 2003. Research on plant-parasitic nematode biology conducted by the United States Department of Agriculture-Agricultural Research Service. Pest Management Science (formerly Pesticide Science), 59 (6-7): 748-753.

Dale, M. F. B., 1988. Breeding for tolerance to potato cyst nematode. Aspects of Applied Biology, 17 (1): 95-101.

Demirbaş Pehlivan, H., G. Kaşkavalcı, E. B. K. Uludamar, H. Toktay \& H. Elekcioğlu, 2020. Identification and prevalence of potato cyst nematodes and root-knot nematodes in the potato production areas of İzmir Province, Turkey. Turkish Journal of Entomology, 44 (2): 259-272.

Enneli, S. \& G. Öztürk, 1996." Important Plant parasitic nematodes damaging potatoes in Central Anatolia Region in Turkey, 396-403". Proceedings of the Third Turkish National Congress of Entomology (24-28 September 1996, Ankara, Turkey) Ankara University Printing House, 716 pp.

EPPO, 2013. European and Mediterranean Plant Protection Organization. EPPO Bulletin, 43: 471-495.

FAOSTAT, 2020. Food and Agriculture Organization Statistical Database. (Web page: http://www.fao.org/faostat/en/\#data/QC) (Date accessed: 15 March 2020).

Felsenstein, J., 1985. Confidence limits on phylogenies: An approach using the bootstrap. Evolution, 39 (4): 783-791.

Ferris, V. R., J. M. Ferris \& J. Faghihi, 1993. Variations in spacer ribosomal DNA in some cyst-forming species of plant parasitic nematodes. Fundamental and Applied Journal of Nematology, 16 (2): 177-184. 
Identification, distribution and genetic diversity of Globodera rostochiensis (Wollenweber, 1923) Skarbilovich, 1959 (Tylenchida: Heteroderidae) populations in Turkey

Ferris, V. R., L. I. Miller, J. Faghihi \& J. M. Ferris, 1995. Ribosomal DNA comparisons of Globodera from two continents. Journal of Nematology, 27 (3): 273-283.

Fleming, C. C. \& T. O. Powers, 1998. "Potato Cyst Nematodes: Species, Pathotypes and Virulence Concepts, 51-57". In: Potato Cyst Nematodes Biology, Distribution and Control (Eds. R. J. Marksand \& B. B. Brodie). CAB International, $424 \mathrm{pp}$.

Ganguly, A. K. \& U. Rao, 2003. "Application of Molecular Biology in Nematology, 312-317”. In: Advances in Nematology (Ed. P. C. Trivedi). Scientific Publishers, 317 pp.

Gitty, M. \& Z. Tanha Maafi, 2010. First report of a potato cyst nematode, Globodera rostochiensis, on potato in Iran. Plant Pathology, 59 (2): 412.

Golden, A. M., 1986. "Morphology and Identification of Cyst Nematodes, 23-79". In: Cyst Nematodes (Eds. F. Lamberti \& C. E. Taylor). Plenum Press, 478 pp.

Golden, A. M., 1990. "Preparation and Mounting Nematodes for Microscopic Observation, 197-205". In: Plant Nematology Laboratory Manual (Eds. B. M. Zuckerman, W. F. Mai \& L.R. Krusberg). Amherst MA Press, 115 pp.

Golden, A. M. \& D. M. S. Ellington, 1972. Redescription of Heterodera rostochiensis (Nematoda: Heteroderidae) with a key and notes on closely related species. Proceedings of the Helminthological Society of Washington, 39 (1): 64-78.

Greco, N., M. Di Vito, A. Brandonisio, I. Giordano \& G. De Marinis, 1982. The effect of Globodera pallida and G. rostochiensis on potato yield. Nematologica, 28 (4): 379-386.

Holterman, M., A. Van Der Wurff \& S. Van Den Elsen, 2006. Phylum-wide analysis of SSU rDNA reveals deep phylogenetic relationships among nematodes and accelerated evolution toward crown clades. Molecular Biology and Evolution, 23 (9): 1792-1800.

Hooper, D. J., 1970. Handling, fixing, staining and mounting nematodes. Ministry of Agriculture, Fisheries and Food's Technical Bulletin, 5 (2): 39-54.

Ibrahim, I. K. A., Z. A. Handoo \& A. A. El-Sherbiny, 2000. A survey of phytoparasitic nematodes on cultivated and noncultivated plants in Northwestern Egypt. Journal of Nematology, 32 (4S): 478- 485.

Imren, M., 2018. Determination of plant parasitic nematodes in potato growing areas in Bolu Province. International Journal of Agriculture and Wildlife Science, 4 (2): 26-32.

Indarti, S., B. Mulyadi \& B. Triman, 2004. First record of potato cyst nematode Globodera rostochiensis in Indonesia. Australasian Plant Pathology, 33 (2): 325-326.

Jones, J. T., A. Haegeman, E. Danchin, H. Gaur, J. Helder, M. G. Jones, T. Kikuchi, R. Manzanilla-López, J. E. Palomares-Rius, W. M. Wesemael \& R. N. Perry, 2013. Top 10 plant-parasitic nematodes in molecular plant pathology. Molecular Plant Pathology, 14 (9): 946-961.

Kepenekci, İ., 2012. Nematology (Plant Parasitic and Entomopathogen Nematodes). Education Directorate of Publications and Publications, Agricultural Science Series, 1155 pp.

Knoetze, R., A. Swart \& L. R. Tiedt, 2013. Description of Globodera capensis n. sp. (Nematoda: Heteroderidae) from South Africa. Nematology, 15 (2): 233-250.

Kort, J., H. Ross, H. J. Rumpenhorst \& A. R. Stone, 1977. An international scheme for identifying and classifying pathotypes of potato cyst nematodes Globodera rostochiensis and G. pallida. Nematologica, 23 (3): $333-339$.

Kumar, S., G. Stecher, M. Li, C. Knyaz \& K. Tamura, 2018. MEGA X: molecular evolutionary genetics analysis across computing platforms. Molecular Biology and Evolution, 35 (6): 1547-1549.

Madani, M., S. A. Subbotin \& M. Moens, 2005. Quantitative detection of the potato cyst nematode, Globodera pallida, and the beet cyst nematode, Heterodera schachtii, using real-time PCR with SYBR green I dye. Molecular and Cellular Probes, 19 (2): 81-86.

Madani, M., S. A. Subbotin, L. J. Ward, X. Li \& S. H. De Boer, 2010. Molecular characterization of Canadian populations of potato cyst nematodes, Globodera rostochiensis and G. pallida using ribosomal nuclear RNA and cytochrome b genes. Canadian Journal of Plant Pathology, 32 (2): 252-263.

Madani, M., L. J. War \& S. H. De Boer, 2008. Multiplex real-time polymerase chain reaction for identifying potato cyst nematodes, Globodera pallida and Globodera rostochiensis, and the tobacco cyst nematode, Globodera tabacum. Canadian Journal of Plant Pathology, 30 (4): 554-564. 
Manduric, S., E. Olsson, J. E. Englund \& S. Andersson, 2004. Separation of Globodera rostochiensis and G. pallida (Tylenchida:Heteroderidae) using morphology and morphometrics. Nematology, 6 (2): 171-181.

Mugniéry, D., M. S. Phillips, H. J. Rumpenhorst, A. R. Stone, A. Treur \& D. L. Trudgill, 1989. Assessment of partial resistance of potato to, and pathotype and virulence differences in, potato cyst nematodes. EPPO Bulletin, 19 (1): 7-25.

Özarslandan, A., D. Dinçer, R. Bozbuga, M. İmren \& I. H. Elekçioğlu, 2019. Study on the presence of potato cyst nematodes: Globodera rostochiensis (Wollenweber, 1923) Skarbilovich, 1959 and Globodera pallida Stone 1973 (Tylenchida: Heteroderidae) in Nevşehir Province, Turkey. Turkish Journal of Agriculture and Natural Sciences, 6 (2): 125-129.

Sasser, J. N. \& D. W. Freckman, 1987. "A World Perspective on Nematology: The Role of the Society, 7-14". In: Vistas on Nematology (Eds. A. Veech \& D. W.Dickerson). Journal of Society of Nematologists, 509 pp.

Scurrah, M. I., B. Niere \& J. Bridge, 2005. "Nematode Parasites of Solanum and Sweet Potatoes, 193-219". In: Plant Parasitic Nematodes in Subtropical and Tropical Agriculture (Eds. M. Luc, R. A. Sikora \& J. Bridge). CABI Publishing, $841 \mathrm{pp}$.

Shapiro, S. S. \& M. B. Wilk, 1965. An analysis of variance test for normality (complete samples). Biometrika, 52 (3/4): 591-611.

Siddiqi, M. R., 2000. Tylenchida, Parasites of Plants and Insects. CABI Publishing, 848 pp.

Skantar, A. M., Z. A. Handoo, L. K. Carta \& D. J. Chitwood, 2007. Morphological and molecular identification of Globodera pallida associated with potato in Idaho. Journal of Nematology, 39 (2): 133-144.

Southey, J. F., 1986. Laboratory Methods for Work with Plant and Soil Nematodes. London: CABI Publishing, 202 pp.

Subbotin, S. A., A. Mundo-Ocampo \& J. G. Baldwin, 2010 Systematics of Cyst Nematodes (Nematode: Heteroderinae). Nematology Monographs and Perspectives, 8A. Brill, 364 pp.

Subbotin, S., R. Perry, A. Warry \& P. Halford, 2000. Variations in ribosomal DNA sequences and phylogeny of Globodera parasitizing solanaceous plants. Nematology, 2 (6): 591-604.

Subbotin, S. A., D. Sturhan, H. J. Rumpenhorst \& M. Moens, 2003. Molecular and morphological characterization of the Heterodera avenae species complex (Tylenchida: Heteroderidae). Nematology, 5 (4): 515-538.

Subbotin, S. A., L. Waeyenberge, I. A. Molokanova \& M. Moens, 1999. Identification of Heterodera avenae group species by morphometrics and rDNA-RFLPs. Nematology, 1 (2): 195-207.

Szalanski, A. L., D. D. Sui, T. S. Harris \& T. O. Powers, 1997. Identification of cyst nematodes of agronomic and regulatory concern with PCR-RFLP of ITS1. Journal of Nematology, 29 (3): 255-267.

Tamura, K. \& M. Nei, 1993. Estimation of the number of nucleotide substitutions in the control region of mitochondrial DNA in humans and chimpanzees. Molecular Biology Evolution, 10 (3): 512-526.

Thompson, J. D., D. G. Higgins \& T. J. Gibson, 1994. CLUSTAL W: improving the sensitivity of progressive multiple sequence alignment through sequence weighting, position-specific gap penalties and weight matrix choice. Nucleic Acids Research, 22 (22): 4673-4680.

Toktay, H., E. Evlice, M. Imren, G. Özer, M. A. Ali \& A. Dababat, 2020. Characterization of potato golden cyst nematode populations (Globodera rostochiensis) in Turkey. International Journal of Agriculture and Biology, 23 (6): 10951100.

Ulutaş, E., A. Özarslandan, G. Kaşkavalcı \& İ. H. Elekcioglu, 2012. Ege Bölgesi patates alanlarında Globodera rostochiensis Wollenweber, 1923' in moleküler yöntemlerle saptanması. Türkiye Entomoloji Dergisi, 36 (1): 155160.

Waeyenberge, L., A. Ryss, M. Moens, J. Pinochet \& T. Vrain, 2000. Molecular characterisation of 18 Pratylenchus species using rDNA restriction fragment length polymorphism. Nematology, 2 (2): 135-142.

Wouts, W. M. \& J. G. Baldwin, 1998. "Taxonomy and Identification, 83-122". In: The Cyst Nematodes (Ed. S. B. Sharma). Dordrecht, Kluwer, 452 pp. 